\title{
The roles of p38MAPK and caspase- 3 in DADS-induced apoptosis in human HepG2 cells
}

\author{
Chunxiao $\mathrm{Ji}^{+1}$, Fenglian Ren ${ }^{* 1}$, Heng Ma² and Ming Xu²
}

\begin{abstract}
Objectives: To explore the function of p38MAPK and caspase-3 in DADS-induced apoptosis in human HepG2 cells, and discuss the signal transduetion mechanism of HepG2 cells in the apoptosis process induced by DADS by using the inhibitors of p38MAPK (SB203580) and caspase-3 (Z-DEVD-FMK).

Methods: After the human HepG2 cells had been treated with the DADS and inhibitors for $24 \mathrm{~h}$, cell viability was determined by the MTT method, apoptosis was evaluated by flow cytometry (FCM) and the expressions of p38MAPK and caspase-3 were measured by western-blot.

Results: Our results indicated that DADS activities the p38MAPK and caspase-3, but the inhibitors, SB203580 and ZDEVD-FMK (for p38MAPKand for caspase-3, respectively), both have the effect of inhibitory activity on P38MAPK and caspase-3. Furthermore, a combination treatment with both DADS and inhibitor (SB203580 or Z-DEVD-FMK) decreases the inhibitory and apoptotic activity of HepG2 cells increased compared with DADS-treated.

Conclusions: Our data indicate that p38MAPK and caspase-3 are involved in the process of DADS-induced apoptosis in human HepG2 cells and interact with each other.
\end{abstract}

\section{Background}

The MAPK (mitogen-activated protein kinase) system is a cluster of serine/threonine protein kinases in the cells, and the activitied MAPKs participate in a variety of cellular responses including genetic transcription, inducing cell apoptosis, maintaining cell and regulating cell cycle, and so on [1-3]. The p38MAPK is the key member of the MAPK family and more commonly activated in response to cytokines, stress and cellular damage [4,5]. A large number of studies have shown that the activity of p38MAPK is necessary in the apoptosis process induced by various anti-cancer drugs. Caspase enzymes play a very important role when cells started apoptosis as the central effector of apoptosis. Caspase-3, is the ultimate enforcer of apoptotic death, which can cleavage many proteins of important structure and function directly[6].

Diallyl disulfide (DADS) is one kind of oil-soluble sulfur organic compounds, it is a potential broad-spectrum anti-cancer drug. Studies have shown that DADS can

\footnotetext{
*Correspondence: renfl2009@yahoo.com.cn

1 College of Chemistry and Chemical Engineering, Central South University,

Changsha, Hunan 410083, China

+ Contributed equally

Full list of author information is available at the end of the article
}

inhibit human tumor cells grow including those of colon, lung, skin, breast, liver origins and prostate [7-10]. There are also lots of reports about the caspase- 3 involvement during apoptosis process with DADS induction, such as The DADS induced apoptosis by the activation of caspase-3 in human leukemia HL-60 cells in a dosedependent manner, DADS promoted caspase- 3 activity and increased cyclin $\mathrm{E}$ and decreased CDK2 gene expression which may lead to the G2/M arrest of T24 cells, Effects of diallyl disulfide (DADS) on expression of apoptosis associated proteins in androgen independent human prostate cancer cells (PC-3) [11,12], and so on. Our previous studies have shown that the activated p38MAPK appears to play a cytoprotective role, and the MAPK specific inhibitors enhance apoptotic effects in HepG2 hepatoma cells with DADS treatment[13]. In this report we used the inhibitors of p38MAPK (SB203580) and caspase-3 (ZDEVD-FMK) to detect the relation of p38MAPK and caspase- 3 in the apoptosis process induced by DADS, we found that P38MAPK and caspase- 3 are involved in the process of DADS-induced apoptosis in human HepG2 cells and interact with eachother. 


\section{Materials and methods Major reagents}

DADS (80\% purity) was purchased from Fluka Co., Dulbecco's modified Eagle medium (DMEM) medium, BSA and SB203580 were purchased from Sigma. Z-DEVDFMK was purchased from CALBIOCHEM (USA), goat horseradish peroxidase (HRP)-conjugated anti-rabbit secondary antibody were purchased from Santa Cruz Biotech. Antibodies to p38, phospho-p38 (p-p38), caspase-3 were purchased from Cell Signaling.

\section{Cell culture}

HepG2 (the human hepatoma cell line) were provided by the Xiangya school of medicine and cultured in DMEM with 10\% heat-inactivated fetal bovine serum (FBS), benzylpenicillin $(100 \mathrm{kU} / \mathrm{L})$ and streptomycin $(100 \mathrm{mg} / \mathrm{L})$ at $37^{\circ} \mathrm{C}$ in an incubator containing humidified air with $5 \%$ $\mathrm{CO}_{2}$.

\section{Cell viability assay}

Cells were seeded into 96-well plates at $1 \times 10^{4}$ cells per well $24 \mathrm{~h}$ before treatment. The cultures were then rinsed in phenol-free DMEM medium and incubated with respective test substances in phenol-free and serumfree DMEM for $24 \mathrm{~h}$. In the inhibition test, Cells were treated with DADS after being treated with inhibitors $30 \mathrm{~min}$. At the end of this time interval, $20 \mu \mathrm{l}(5 \mathrm{mg} / \mathrm{ml})$ MTT [3(4,5dimethylthiazol-2-yl)-2,5-diphenyltetrazolium bromide] was added to each well, and after incubation at $37^{\circ} \mathrm{C}$ for $4 \mathrm{~h}$ the MTT solution was removed and $200 \mu \mathrm{l}$ of dimethylsulfoxide (DMSO) was added to dissolve the crystals. The absorbance of each well at $570 \mathrm{~nm}$ was measured.

\section{Flow cytometry analysis}

Cells were seeded into $100 \mathrm{ml}$ cell culture bottles at $12 \times$ $10^{6}$ cells $24 \mathrm{~h}$ before treatment. Then cells were treated according to the aforementioned method and incubated for $24 \mathrm{~h}$. Afterwards, cells were collected, made into single cell suspension and centrifuged at $800 \mathrm{~g}$ for $5 \mathrm{~min}$. Discard the supernatant, washed cells three times with the cool PBS and fixed them $24 \mathrm{~h}$ with cool alcohol at $4^{\circ} \mathrm{C}$. Taked $1 \mathrm{ml}$ cell suspension $\left(10^{6} / \mathrm{ml}\right)$, washed it three times with the cool PBS, treated it with RNase for $30 \mathrm{~min}$ at $37^{\circ} \mathrm{C}$, and stained it with PI for $30 \mathrm{~min}$ at $37^{\circ} \mathrm{C}$ in a dark environment. Then the flow cytometry analysis can be carried out.

\section{Western-blotting}

Taked the cells in the logarithmic growth phase, treated them according to the aforementioned method and incubated for $24 \mathrm{~h}$. After fragmentation on ice for $20 \mathrm{~min}$, the lysates were centrifuged at $15,000 \mathrm{~g}$ for $10 \mathrm{~min}$ at $4^{\circ} \mathrm{C}$, collected the protein and quantitated it with the BCA method, electrophoresed and isolated protein by the
SDS-PAGE (10\%), used the electrotransfer method, carried out the blocking and hybridization on the cellulose nitrate film, detected the protein expression of cells using the ECL western blotting method. The densities of protein bands were calculated using the Quantyone software.

\section{Statistics}

Data are expressed as mean \pm S.D of three independent experiments and evaluated by one-way analysis of variance (ANOVA). Significant differences were established at $\mathrm{P}<0.05$.

\section{Results}

\section{Changes of cell activity}

Cell viability was determined by the MTT assay. As shown in Figure 1. After treatment and incubated for 24 $\mathrm{h}$, the inhibition ratio of treated with $10 \mu \mathrm{mol} / \mathrm{L}$ SB203580 and $100 \mu \mathrm{mol} / \mathrm{L}$ DADS was $19.45 \%$ at $24 \mathrm{~h}$, and the inhibition ratio of treated with $10 \mu \mathrm{mol} / \mathrm{L}$ Z-DEVDFMK and $100 \mu \mathrm{mol} / \mathrm{L}$ DADS was $17.64 \%$ at $24 \mathrm{~h}$, both of them were lower than the inhibition ratio of treated with $100 \mu \mathrm{mol} / \mathrm{L}$ DADS at $24 \mathrm{~h}$, but they were both higher than the inhibition ratio of treated with $10 \mu \mathrm{mol} / \mathrm{L}$ SB203580 and $10 \mu \mathrm{mol} / \mathrm{L}$ Z-DEVD-FMK respectively (9.73\% and 6.77\%).

\section{Flow-cytometric analysis of apoptosis}

The results of flow cytometry analysis showed, the rate of SB203580-DADS group and SB203580-Z-DEVD-FMK group was $18.98 \%$ and $17.45 \%$ respectively, $1.86 \%$ of control group, $8.50 \%$ when treated with SB203580 $(10 \mu \mathrm{mol} /$ L), 6.02\% when treated with Z-DEVD-FMK $(10 \mu \mathrm{mol} / \mathrm{L})$, and $25.23 \%$ when treated with DADS (Figure 2). These results suggested that inhibitors of P38MAPK and cas-

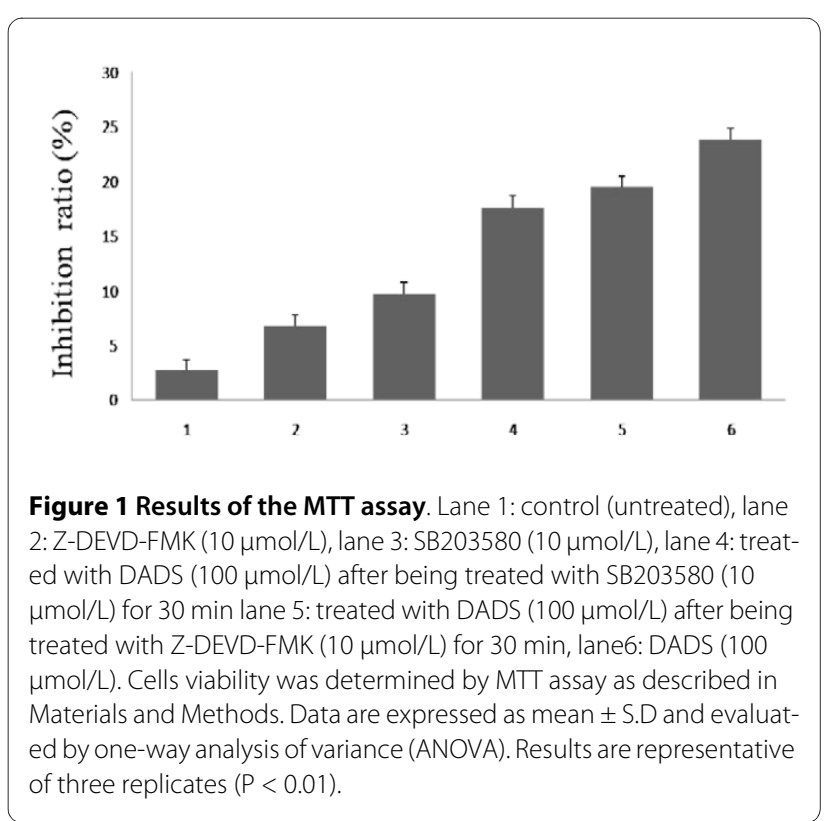


$\mathbf{A}$

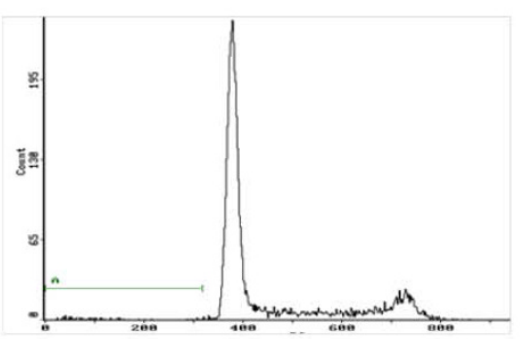

C

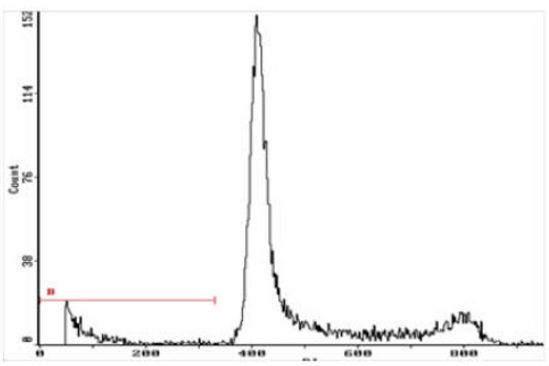

$\mathbf{E}$

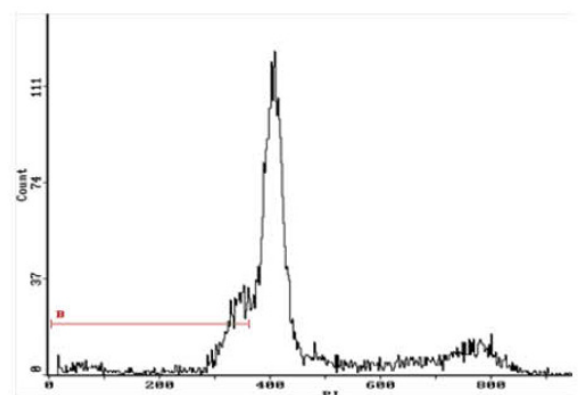

B

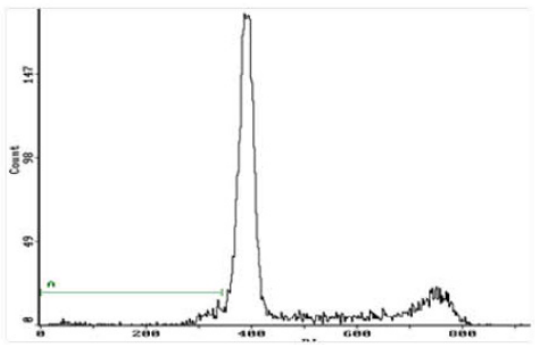

D

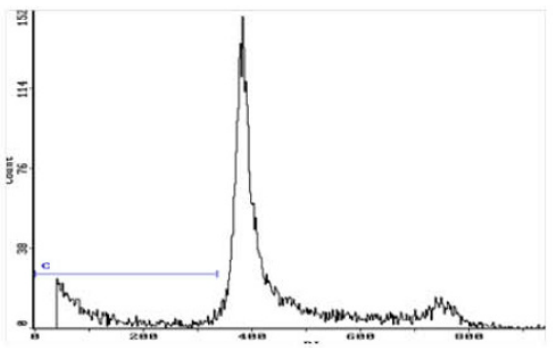

F

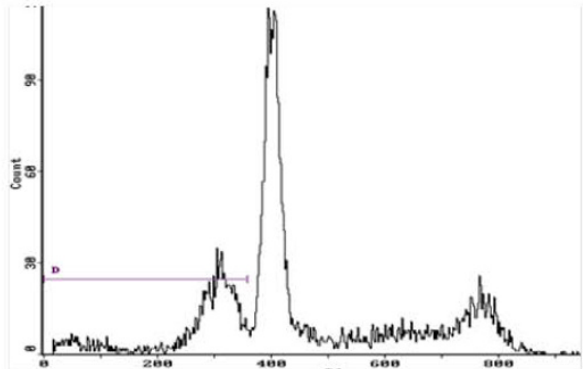

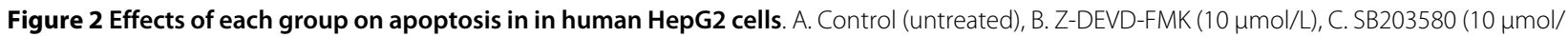
$\mathrm{L})$, D. treated with DADS $(100 \mu \mathrm{mol} / \mathrm{L})$ after being treated with SB203580 $(10 \mu \mathrm{mol} / \mathrm{L})$ for $30 \mathrm{~min}$, E. treated with DADS $(100 \mu \mathrm{mol} / \mathrm{L})$ after being treated with Z-DEVD-FMK (10 $\mu \mathrm{mol} / \mathrm{L})$ for $30 \mathrm{~min}$, F. DADS (100 umol/L). Results are representative of three replicates $(P<0.01)$.

pase-3 both had obvious effect of inhibiting apoptosis (Figure 3).

\section{Western-blot analysis}

After various treatment for $24 \mathrm{~h}$, the zymogen bands of caspase- 3 treated with DADS $(100 \mu \mathrm{mol} / \mathrm{L})$ became thinner significantly compared with the control gtoup, proving that DADS could advance the activity of caspase-3; after treated with SB203580 $(10 \mu \mathrm{mol} / \mathrm{L})$ and Z-DEVDFMK $(10 \mu \mathrm{mol} / \mathrm{L})$ respectively, the zymogen bands of caspase-3 became thicker significantly compared with treated with DADS $(100 \mu \mathrm{mol} / \mathrm{L})$, but compared with the DADS $(100 \mu \mathrm{mol} / \mathrm{L})$ group that 30 minutes ahead of schedule by adding inhibitor, the band is only slightly thinner (Figure 4).
Similarly, SB203580 (10 $\mu \mathrm{mol} / \mathrm{L})$ and Z-DEVD-FMK $(10 \mu \mathrm{mol} / \mathrm{L})$ had inhibition effect on the P-p38 MAPK, When SB203580(or Z-DEVD-FMK) was added to HepG2 hepatoma cells for $30 \mathrm{~min}$ before DADS treatment or only added SB203580 (or Z-DEVD-FMK) to HepG2 hepatoma cells, P-p38 MAPK was markedly decreased, but DADS induced activations of P-p38 MAPK, compared to DADS-treatment alone or no treatment (Figure 4).

These results confirm that SB203580 and Z-DEVDFMK could inhibit the activity of P-p38 MAPK and caspase-3. But the inhibition of SB203580 was stronger than Z-DEVD-FMK, comparatively (Figure 5). 


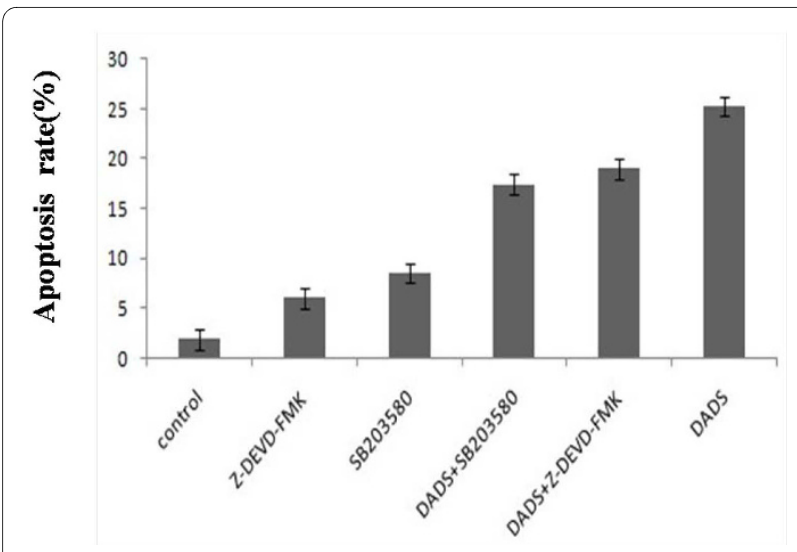

Figure 3 Results of the flow cytometry analysis. Data are expressed as mean \pm S.D and evaluated by one-way analysis of variance (ANOVA). The results are representative of three independent experiment.

\section{Discussion}

Apoptosis is a very complex process with the complexity and diversity, different cells in different stress have different signal transduction pathways. Extracellular signals how pass to cells and cause cells to the corresponding reaction is very important to the occurrence of apoptosis in the process of cell apoptosis.

The MAPK (mitogen-activated protein kinase) system is a cluster of intracellular serine/threonine protein kinases, playing an important role in a variety of signal transduction pathways of the mammalian cells. In recent years, many research report that apoptosis signal transduction and activation of caspase have a closely relationship, and have found 16 members of caspase family in mammalian cells [14-16]. All the Caspase exit in the form of inactive zymogen, can lead to caspase cascade reaction after be activitied, and eventually induce apoptosis. Undynamic caspase-3 will trigger apoptosis when it is activitied, and play a very important role when cells

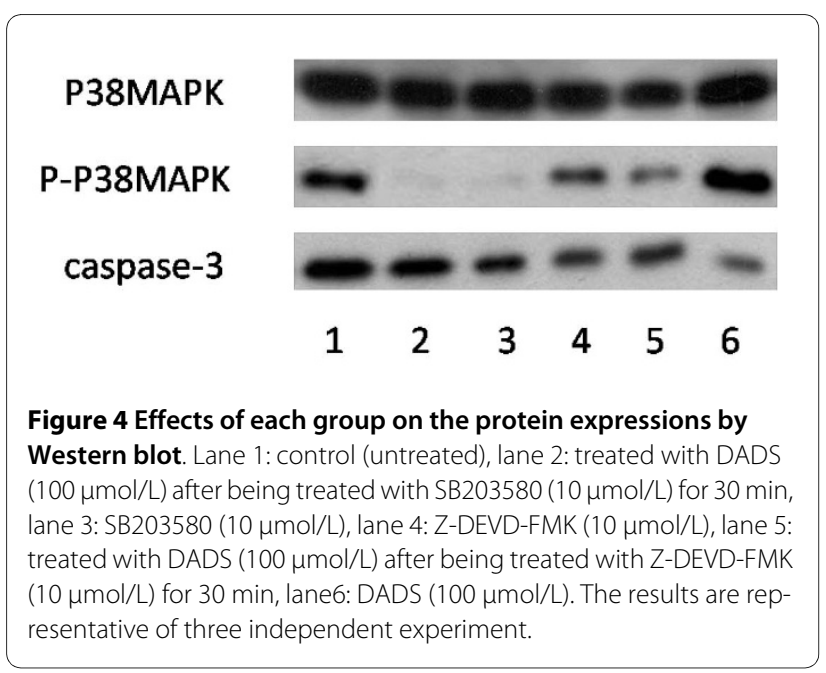

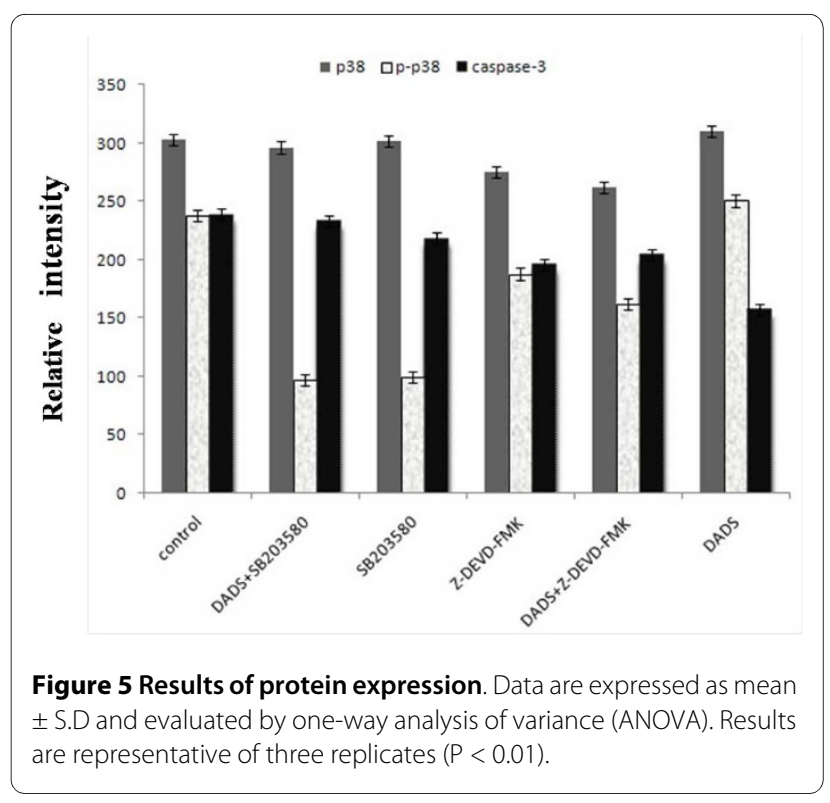

started apoptosis as the central effector of apoptosis [1720].

Our previous work has demonstrated that DADS transiently activates both p38MAPK and p42/44MAPK while it induces apoptosis in a time and dose dependent manner in human HepG2 hepatoma cells[13]. The present study focuses on the role of p38MAPK and caspase- 3 in cell apoptosis and DADS-induced apoptosis. To test the relation of p38MAPK and caspase-3 in the apoptosis process of human HepG2 cells induced by DADS, we used the inhibitors of p38MAPK (SB203580) and caspase-3 (ZDEVD-FMK), the methods of MTT, flow cytometry analysis and western blot, The results presented in this study established a potential role for inhibitors of p38MAPK and caspase-3 in DADS-induced apoptosis. First, inhibitor (SB203580 or Z-DEVD-FMK) have the effect of inhibitory activity on p38MAPK and caspase-3. Second, a combination treatment with both DADS and inhibitor (SB203580 or Z-DEVD-FMK) decreases the inhibitory and apoptotic activity of HepG2 cells increased compared with DADS-treated (Figure 1, Figure 3, Figure 4 and Figure 5). The combined effect suggests a co-chemocytotoxic value in human HepG2 cells. In conclusion, our results show that $\mathrm{p} 38 \mathrm{MAPK}$ and caspase- 3 are involved in the process of DADS-induced apoptosis in human HepG2 cells and interact with each other.

At present, there have made some progress on the effect of MAPK signaling pathway in cellular apoptosis, but need in-depth study to fully reveal its mechanisms of action. Our results show that p38MAPK and caspase-3 are involved in the process of DADS-induced apoptosis in human HepG2 cells, enhance DADS-induced apoptosis and interact with each other, but its mechanism remains to be further discussed [21-24]. Further study the rela- 
tionship of MAPK signal transduction pathway and caspase in the cellular apoptosis process, will have important significance for studying anti-tumor mechanisms of DADS and designing new drugs.

\section{Competing interests}

The authors declare that they have no competing interests.

\section{Authors' contributions}

FR, MX and CJ designed the experiments. CJ carried out most of experiments and drafted the manuscript. HM carried out partial experiments. All authors read and approved the final manuscript.

\section{Author Details}

${ }^{1}$ College of Chemistry and Chemical Engineering, Central South University, Changsha, Hunan 410083, China and ${ }^{2}$ Research Institute for Molecular Pharmacology and Therapeutics, Central South University, Changsha, Hunan 410083, China

Received: 10 April 2010 Accepted: 18 May 2010

Published: 18 May 2010

\section{References}

1. Tian W, Zhang Z, Cohen DM: MAPK signaling and the kidney. Am J Physiol Renal Physio/ 2000, 279:593-604

2. Widmann C, Gibson S, Jarpe MB: Mitogen-activated protein kinase: conservation of a three-kinase module from yeast to human. Physiol Rev 1999, 79:143-180

3. Tortora G, Bianco R, Daniele G: Overoming resistance to molecularly targeted anticancer therapies: Rational drug combinations based on EGFR and MAPK inhibition for solid tumours and haematologic malignancies. Drug Resist Updat 2007, 10:81-100.

4. Mendelson KG, Contois LR, Tevosian SG, Davis RJ, Paulson KE: Independent regulation of JNK/p38 mitogen-activated protein kinases by metabolic oxidative stress in the liver. Proc Natl Acad Sci USA 1996, 93:12908-13.

5. Niisato N, Post M, van Driessche W, Marunaka Y: Cell swelling activates stress-activated protein kinases, p38MAP kinase and JNK, in renal epithelial A6 cells. Biochem Biophys Res Commun 1999, 266:547-50.

6. Ronit $\mathrm{H}$, Liola L, Hongein Li, Junying Yuan, Reuven S: Need for caspases in apoptosis of trophic factor-deprived PC12 cells. J Neuronsci Res 1997, 50:69-80.

7. Park EK, Kwon KB, Park KI: Role of Ca2+ in diallyl diaulfide-induced apoptotic cell death of HCT-15 cells. Exp Mol Med 2002, 34:250-257.

8. Hong YS, Ham YA, Choi JH: Effects of diallyl disulfur compounds and garlic extract on the expression of $\mathrm{BCl}-2, \mathrm{Bax}$, and $\mathrm{p} 53$ in non-small lung cancer cell lines. Exp Mol Med 2000, 32:127-134.

9. Nakagawa H, Tsuta K, Kiuchui K: Growth inhibitory effects of diallyl disulfide on human breast cancer cell lines. Carcinogenesis 2001, 22:891-897.

10. Nagathihalli SN, Kandangath RA, Om VS: Diallyl disulfide causes caspasedependent apoptosis in human cancer cells through a Bax-triggered mitochondrial pathway. J Nutritional Biochem 2010, 21:405-412.

11. Kwon KB, Yoo SJ, Ryu DG, Yang JY, Rho HW, Kim JS: Induction of apoptosis by diallyl disulfide through activation of caspase-3 in human leukemia HL-60 cells. Biochem Pharmacol 2002, 63:41-47.

12. Gayathri R, Gunadharini DN, Arunkumar A: Effects of diallyl disulfide (DADS) on expression of apoptosis associated proteins in androgen independent human prostate cancer cells (PC-3). Molecular and Cellular Biochemistry 2009, 320:197-203.

13. Wen J, Zhang YW, Xu M: Enhancement of diallyl disulfide-induced apoptosis by inhibitors of MAPKs in human HepG2 hepatoma cells. Biochem Pharmacol 2004, 68:323-331.

14. Lu HF, Sue CC, Yu CS: Diallyl disulfide(DADS) induced apoptosis undergo capase-3 activity in human bladder cancer T24 cells. Food Chem Toxicol 2004, 42:1543-1552.

15. Marks N, Berg MJ: Recent advances on neuronal caspases in development and neurodegeneration. Neuroehem Int 1999, 35:195-220

16. Henkels KM, Turchi JJ: Cisplatin-induced apoptosis proceeds by caspases-3 dependent and independent path ways in cisplatin resistant and sensitive human ovarian cancer cell lines. Cancer Res 1999, 59:3077-3083.

17. Chen YC, Shen SC: Emodin induces apoptosis in human promyeloeukemic HL-60 cells accompained by activation of caspase-3 cascade but independent of reactive oxygen species production. Biochem Pharmacol 2002, 64:1713-1724.

18. Holmanova J, Vaeulova A, Kozubik A: Polvunsaturated fattyacids sensitize human colon adenocarcinoma HT-29 cells to death receptormediatedapoptosis. Cancer Lett 2005, 218:33-41.

19. Kwon KB, Yoo SJ, Ryu DG: Induction ofapoptosis by dia11yl disulfide through activation of Caspase-3 in human leukemia HL-60 cells. Biochem Pharmaeol 2002, 63:41-47.

20. Zhu XF, Liu ZC, Xie BF: Involvement of caspase-3 activation in squamocin-induced apoptosis in leukemia cell line HL-60. Life Sci 2002, 70:1259-1269

21. Wen Jun, Wang Xiao Chun: Mitogen-activated protein kinase inhibitors induce apoptosis and enhance the diallyl disulfide-induced apoptotic effect in human CNE2 cells. Journal of Health Science 2008, 54:129-136.

22. Xiao Dong, Choi Sunga: Diallyl trisulfide-induced apoptosis in human prostate cancer cells involves c-Jun $\mathrm{N}$-terminal kinase and extracellular-signal regulated kinase-mediated phosphorylation ofBcl2. Oncogene 2004, 23:5594-5606.

23. Fan Yumei, Chen Hui: Opposing effects of ERK and P38 MAP kinases on Hela cell apoptosis induced by dipyrithione. Molecules and Cells 2007, 23:30-38

24. Wu June $\mathrm{H}$, Hong Li-Chun: Mitogen-activated protein kinase(MAPK) signalling pathways in HepG2 cells infected with a virulent strain of klebsiella pneumoniae. Cellular Microbiology 2006, 8:1467-1474.

doi: 10.1186/1756-9966-29-50

Cite this article as: Ji et al., The roles of p38MAPK and caspase-3 in DADSinduced apoptosis in human HepG2 cells Journal of Experimental \& Clinical Cancer Research 2010, 29:50

\section{Submit your next manuscript to BioMed Central and take full advantage of:}

- Convenient online submission

- Thorough peer review

- No space constraints or color figure charges

- Immediate publication on acceptance

- Inclusion in PubMed, CAS, Scopus and Google Scholar

- Research which is freely available for redistribution

Submit your manuscript at www.biomedcentral.com/submit
C) BioMed Central 